\title{
Morphology of bromeliad-associated immature stages of Daiphron bipartitus and its adults confirms the non-monophyly of the genus (Coleoptera: Cantharidae)
}

\author{
Gabriel BIFFI ${ }^{1)} \&$ Simone Policena ROSA ${ }^{2)}$

\begin{abstract}
1) Museu de Zoologia da Universidade de São Paulo, Av. Nazaré, 481 - Ipiranga, 04263-000, São Paulo, SP, Brazil; e-mail: biffigabriel@gmail.com
${ }^{2)}$ Universidade Federal de Itajubá, Instituto de Recursos Naturais. Avenida BPS, 1.303, Bairro Pinheirinho, CEP 37500-185, Itajubá, MG, Brasil; e-mail: simonepolicena@unifei.edu.br
\end{abstract}

Accepted:

$13^{\text {th }}$ March 2019

Published online: $18^{\text {th }}$ March 2019

\begin{abstract}
Daiphron bipartitus Pic, 1934 is a poorly known species whose systematic position in the subfamily Chaulioganthinae is still controversial. In this paper we describe immature stages of D. bipartitus which were found inhabiting fallen bromeliads Vriesea bituminosa in southeastern Brazilian Atlantic forest. Adults are redescribed, including the first study of male and female genitalia. Larva, pupa and adult are illustrated in detail and compared with other species of Daiphron Gorham, 1881 and Chauliognathus Hentz, 1830. We discuss the systematic position of Daiphron bipartitus within Chauliognathinae on the basis of morphological comparison of its immature and adult characters. Both were found to be more similar to species of Chauliognathus than to Daiphron mediofasciatum Pic, 1949, which supports the hypothesis of polyphyly of Daiphron. Aspects of the species biology and occasional association with bromeliads are discussed.
\end{abstract}

Key words. Coleoptera, Cantharidae, Chauliognathus, larval morphology, systematics, taxonomy, Bromeliaceae, Vriesea, Brazil, Neotropical Region

Zoobank: http://zoobank.org/urn:lsid:zoobank.org:pub:BA2B16BE-CE3D-4746-94DD-4597E515E640

(C) 2019 The Authors. This work is licensed under the Creative Commons Attribution-NonCommercial-NoDerivs 3.0 Licence.

\section{Introduction}

Immatures of the subfamily Chauliognathinae were recently characterized based on 13 species of Chauliognathus Hentz, 1830, Daiphron Gorham, 1881, Macromalthinus Pic, 1919, and Belotus Gorham, 1881 (BIFFI \& CASARI 2017). Larvae inhabit a wide variety of environments and can be found in the leaf litter, on the ground, deep inside humid soil, under the bark of fallen trees, inside bracket fungi, and amongst bromeliad leaves. All known larvae are predatory (BIFFI \& CASARI 2017).

In recent surveys carried out in Campos do Jordão, São Paulo state (Brazil), cantharid larvae were found living among leaves of Vriesea bituminosa Wawra (Bromeliaceae). They were reared in the laboratory to obtain the adults which were identified as Daiphron bipartitus Pic, 1934 (a replacement name for the junior homonym D. atripenne Pic, 1934; BIFFI 2019).
The species is tentatively allocated to Daiphron Gorham, 1881, a genus characterised by lycid-like traits, such as elongate head, serrate antennae, elytra widening posteriorly, and yellow-black aposematic colouration (BIFFI 2019). However, a morphology-based phylogeny of the Chauliognathinae shows that those characters are homoplastic and the genus is currently polyphyletic, with species arising from several clades within the highly diverse and heterogeneous Chauliognathus Hentz, 1830 (BIFFI 2017a). A morphological study of immatures of $D$. bipartitus may bring further evidence for a reassessment and a more accurate positioning of the species within Chauliognathinae genera.

Here, larva and pupa of D. bipartitus are described, illustrated and compared to the other chauliognathine larvae described so far, especially to the congeneric species Daiphron mediofasciatum Pic, 1949. Male and female adults are redescribed, illustrated and compared with other members of Chauliognathinae. 


\section{Material and methods}

Immatures were collected in a private area within the municipality of Campos do Jordão, São Paulo state, Brazil at elevation of $1,460 \mathrm{~m}$. The region is part of the Mantiqueira Mountain Range ('Serra da Mantiqueira') and is densely covered with fragments of tropical montane cloud forest. The area is interspaced with anthropogenically degraded habitats and exotic tree reforestation, such as Eucalyptus spp., Pinus spp., and Pyrus communis. However, much of its primary species composition remains in 'legal reserves', which include native trees as Podocarpus lambertii Klotzsch ex Endl. (Podocarpaceae), Eremanthus erythropappus (DC.) McLeisch (Asteraceae), Araucaria angustifolia (Bertol.) Kuntze (Araucariaceae), and a high diversity of vascular epiphytes. The climate of Campos do Jordão is classified as a subtropical highland variety of the oceanic climate (' $\mathrm{Cfb}$ ' according to the Köppen climate classification; see Köppen \& Geiger 1928, Котtek et al. 2006), though with wet and dry seasons with higher precipitation levels (Robim \& PFeIFer 1989).

From May 2017 to December 2018 immatures of Elateroidea were investigated in 60 fallen bromeliads following a three-step protocol: 1: leaf blades were examined and cut off to enable easier handling of the remaining plant; 2 : bromeliads water and leaf litter were dumped on a white tray and their contents examined; 3 : from the outside, all leaf sheaths were disassembled, one by one, to search on both surfaces and in their leaf litter. Additionally, during the same period, immatures were searched for in the surrounding soil, leaf litter and in decaying wood.

Specimens were reared in the laboratory of Zoology at the Universidade Federal de Itajubá (UNIFEI) in plastic containers with soil and leaf litter from the collecting area at ambient temperature. Soil was moistened and larvae were fed on termite workers weekly.

The techniques for relaxing, dissecting and fixing the immatures and their exuviae are detailed in CosTA et al. (1988). Pieces of exuviae were dissected and mounted on temporary slides for examination and illustration. Illustrations from slides were made with the aid of a camera lucida, attached to a microscope. Photographs were taken with a Canon EOS Rebel T3i camera equipped with a Canon MP-E $65 \mathrm{~mm}$ macro-lens attached to a Stack Shot macro-rail. Multi-focal images were processed with Zerene Stacker software (version 1.04). Final artwork was edited in Adobe Photoshop CC.

We adopted the morphological terminology for immatures from BIFFI \& CASARI (2017), who adapt the terminology used by RAMSDALE (2010) and LAWRENCE et al. (2010). We use the same terminology for adult morphology and orientation of aedeagus as BIFFI (2016), and follow BRANCUCCI (1980) for wing venation. Female terminalia and genitalia were dissected after a short maceration in $\mathrm{KOH}$ solution and stained with Chlorazol Black E dye.

We preserved larvae, pupa, adults and their exuviae in $70 \%$ ethanol and deposited them in the Coleoptera Immature Collection at MZSP. The examined adult specimens, including types, are deposited in the following institutions:
DZUP Coleção de Entomologia Pe. Jesus Santiago Moure, Universidade Federal do Paraná, Curitiba, Brazil;

MNHN Muséum national d'Histoire naturelle, Paris, France;

MZSP Museu de Zoologia da Universidade de São Paulo, São Paulo, Brazil;

NHMB Naturhistorisches Museum Basel, Basel, Switzerland.

\section{Results}

\section{Daiphron bipartitus Pic, 1934}

$$
\text { (Figs 1-45) }
$$

Daiphron atripenne Pic, 1934: 130; DelKesKamp (1939): 309; BLACKWELDER (1945): 374.

Daiphron (Championellum) proteum var. atripennis: DeLKESKAMP (1977): 463 [altripennis]; Delkeskamp (1978): 491; Biffi (2019): 32 (syn.) [junior homonym of Daiphron polemioides var. atripennis Pic, 1927].

Daiphron atripenne var. bipartitum Pic, 1934: 130; DELKESKAMP (1939): 309; BLACKWELDER (1945): 374.

Daiphron (Championellum) proteum var. bipartita: DeLKesKAMP (1977): 463.

Daiphron bipartitus: BIFFI (2019): 32 (replacement name).

Type material examined. Daiphron atripenne Pic, 1934: Lестотуре: + , Brazil, 'Minas' [= Brazil: Minas Gerais] (MNHN). Paralectotypes: 2 ơ 1 ô, 'Minas' [= Brazil: Minas Gerais] (MNHN).

Daiphron atripenne var. bipartitum Pic, 1934: LeCTOTYPE: 9 , 'Minas' [= Brazil: Minas Gerais] (MNHN). Paralectotypes: 1 q 1 , 'Minas' [= Brazil: Minas Gerais] (MNHN).

Additional material examined. Adults. BRAZIL: Minas Gerais: Vila Monte Verde, ix.1967, J. Halik col. (1 1 \% , MZSP 31007-31008); idem, 17.ix.1971, J. Halik col. (1 +, MZSP 31009); Itajubá (Serra dos Toledos), S.P. Rosa \& D.S. Dias col. (1 đ̃ , MZSP 31010 - spirit collection). São Paulo: Serra da Bocaina, 1500 m, xi.1965 (4 $\delta 1$ †, NHMB); 1600 m, São José do Barreiro, xi.1967, Alvarenga \& Seabra cols. (4 우, DZUP 273492-273495); São José do Barreiro, xi.1969, Alvarenga col. (2 †, MZSP 31011-31012); Campos do Jordão, xi.1936, J. Lane col. (1 ㅇ, MZSP 31013); Campos do Jordão (lot. Quebradas), 1-28.x.2017, Malaise, Rosa col. (1 đ), MZSP 31014 - spirit collection).

Immature stages. BRAZIL: São PAUlo: Campos do Jordão (lot. Quebradas), 22 $2^{\circ} 0^{\prime} 50.1^{\prime \prime} \mathrm{S} 45^{\circ} 35^{\prime} 35.0^{\prime \prime} \mathrm{W}, 25 . v i .2017$, inside bromeliad, Rosa col. (1 larva reared to adult: larval and pupal exuviae, male adult, MZSP 10357); same locality, 27.viii.2017, in the soil (1 larva reared to adult: larval and pupal exuviae, male adult, MZSP 10358); same locality, 5.v.2018, inside bromeliad (1 larva reared to pupa: larval exuvia and pupa, MZSP 10359); same locality, 5.v.2018, inside bromeliad (1 larva reared to adult: larval and pupal exuviae, male adult, MZSP 10360); same locality, ix.2017 ( 1 male and 1 female in copula, MZSP 10361); same locality, 11.viii.2018, inside bromeliad (1 larva, MZSP 10362); idem, 8.xii.2018, inside bromeliad (1 larva, MZSP 10363).

Description of the last instar larva (Figs 1-24, 49-50). Colouration. In fixed specimens, head (Figs 4-5, 8) dark brown to black, dull in basal two thirds; lighter and bright in apical third; limits between dull and bright areas with a sinuous and darker stripe towards base of stemmata. Mandibles (Figs 11-14) dark brown in apical half and brown in basal half. Basal and distal antennomeres light brown, median antennomere dark brown; maxillae and labium light brown, except for palpigers and distal half of postmentum, translucent. Body (Figs 1-7): integument mostly dark greyish brown dorsally, pale yellow along ecdysial line of thorax and anterior part of abdominal segment I; thorax with one pair of longitudinal darker spots: almost contiguous, occupying median two thirds of prothorax, separated on meso- and metathorax, with one third of width of each lateral half; abdomen with pale yellow spots on apex of dorsal ampulla of segments I, IV and VIII, and dark brown lateral stripes on segment IX; ventral surface of prothorax 


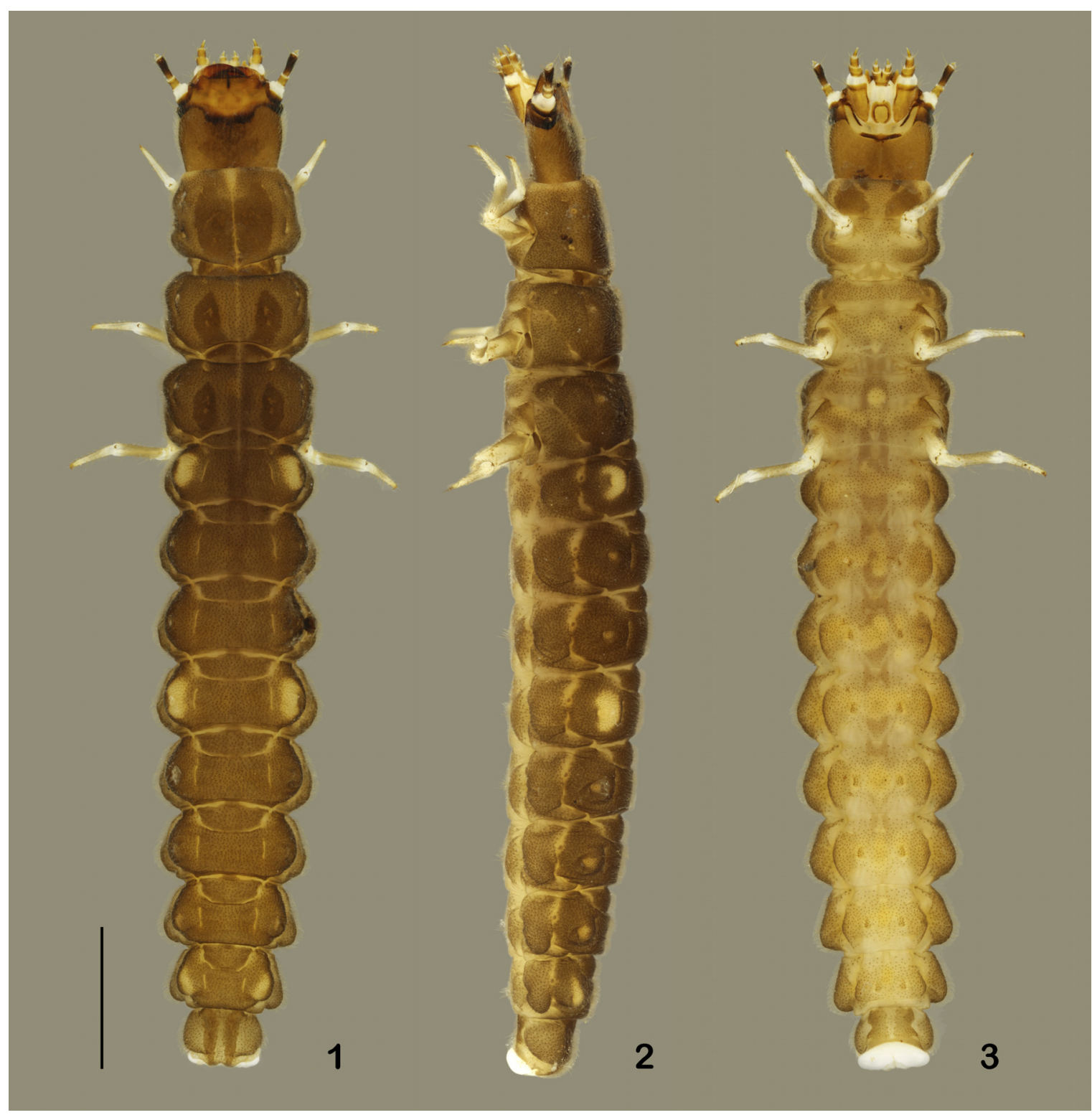

Figs 1-3. Habitus of last instar larva of Daiphron bipartitus Pic, 1934 (dorsal, lateral and ventral). Scale bar: $2.0 \mathrm{~mm}$.

and abdominal segment IX (Figs 4-6) brown with paired darker spots. When alive larval tegument is more greyish dark brown. Legs light brown, translucent on articulating areas; pretarsi brown.

Pubescence moderately long and dense; setae light brown, inserted in dark punctures; abdominal segments II-VIII with paired patches of longer setae.

Structure. Head (Figs 2, 4-5) with lateral margins slightly rounded; partially retracted into prothorax; prognathous and flattened dorso-ventrally; densely covered with fine and long yellow setae on basal third, with a velvety aspect; almost smooth anteriorly; epicranial suture absent; gular suture obsolete. One large stemma on each side, behind antenna. Nasale (Figs 8-10) slightly shorter than paranasal lobes, 5 prominent acute teeth on each side of median incision dorsally; transverse, oblique, sclerotized plate ventrally, with deep irregular grooves on each side; median groove very wide with a small rounded central protuberance; fringe of long setae, longer laterally, appearing dorsally below paranasal lobes, near sclerotized plate. Paranasal lobes longer than nasale, inner margins strongly declivous from apex to nasale; outer angles rounded. Antennae (Figs 18-21) densely setose, with three antennomeres; setae long, longer near apex of median antennomere; basal antennomere elongate, 0.6 times as long as median antennomere; median antennomere cylindrical, apex truncate bearing terminal membranous sensorium on outer margin; sensorium elongate with an sclerotized basal band; median antennomere with two dorsal campaniform sensilla and one tiny wart-like sensorium near apex, between sensorium and distal antennomere; distal antennomere elongate and narrow apically, with one spine-like seta at apex; one third of width of median antennomere, inserted latero-internally at apex of median antennomere, next to sensorium; 6 latero-internal, 6 latero-external, and 3 dorsal setae near base. Mandibles (Figs 11-14) symmetrical, slightly arcuate, incisor acute; retinaculum dorsal, apex round; mesal channel well-developed, extended ventrally at apex, almost straight, 

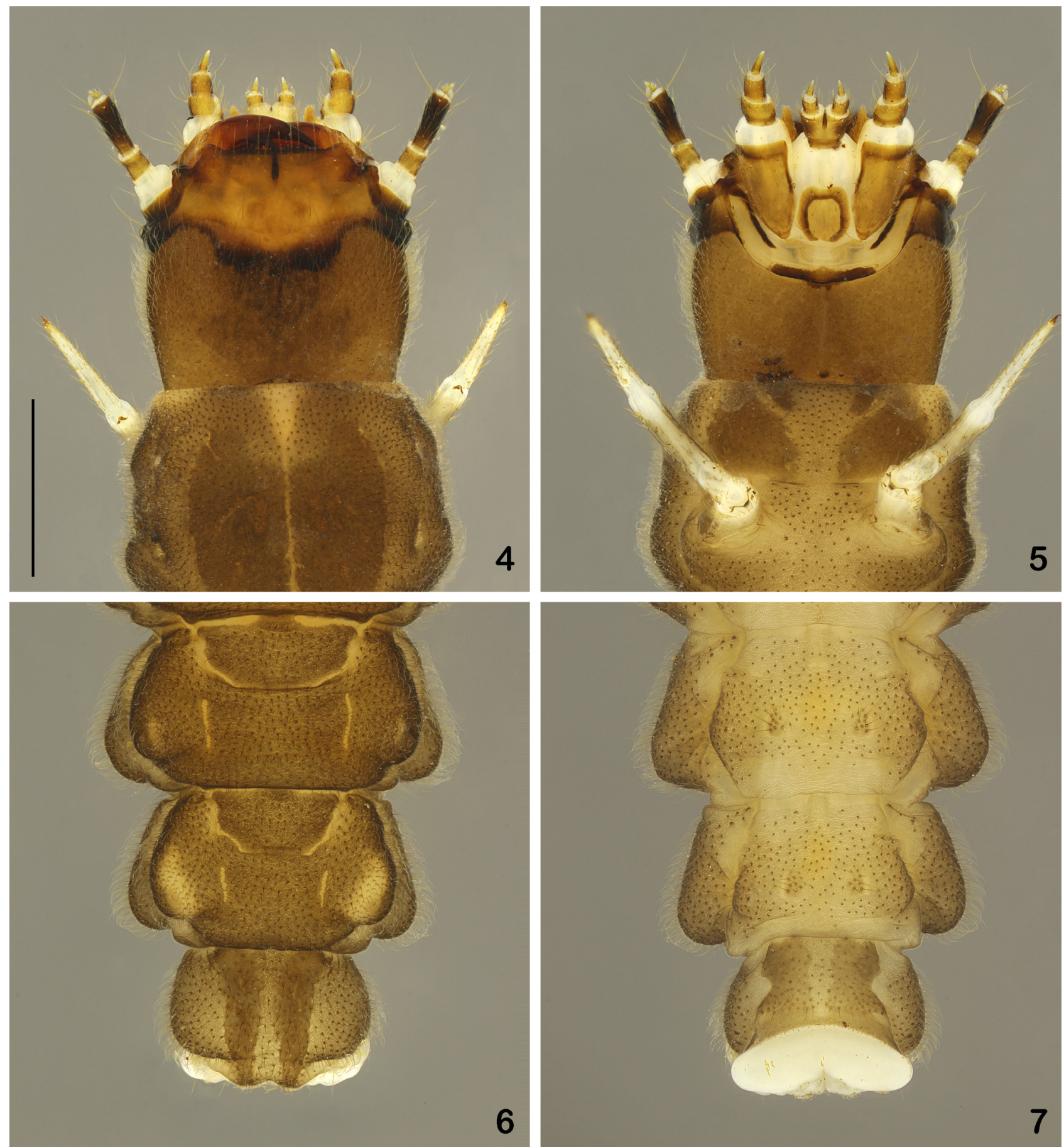

Figs 4-7. Last instar larva of Daiphron bipartitus Pic, 1934. 4-5 - head (dorsally, ventrally); 6-7 -apex of abdomen (dorsally, ventrally). Scale bars: $1.0 \mathrm{~mm}$.

slightly directed dorsally near base; elongate, meso-dorsal, weakly striate concavity below retinaculum; dense fringe of fine yellow setae on ventral margin of distal third of longitudinal channel; penicillus formed by tuft of long yellow setae; a few long yellow setae forming irregular row in basal half, near acetabulum, and a few shorter setae near middle laterally. Maxillae (Figs 15-16). Cardo, elongate, tapering towards apex, weakly sclerotized. Stipes elongate, narrow basally, ventral sclerotized surface with darker transverse band at base of palpigers and numerous long setae along anterior, inner and lateral margins; ventral surface of stipes with microspines near middle and long setae on inner margin and anterior corner, intermingled among long, fine and ramified setae dorsally. Galea (Fig. 17) minute, elongate and narrow, one-segmented, located dorsally near apex of stipes, bearing one long seta near middle. Lacinia formed by fringe of short and long, fine and ramified setae densely distributed near inner margin. Maxillary palpi with three palpomeres; densely setose, except for distal palpomere, which bears two setae; setae long, denser dorsally; basal palpomere wider than long, with transverse sclerotized band at base; median palpomere longer than wide with two ventral campaniform sensilla near apex; distal palpomere elongate, tapering apicad with one lateral seta ventrally and one inner seta dorsally, and campaniform sensillum ventrally at base. Labium (Figs 

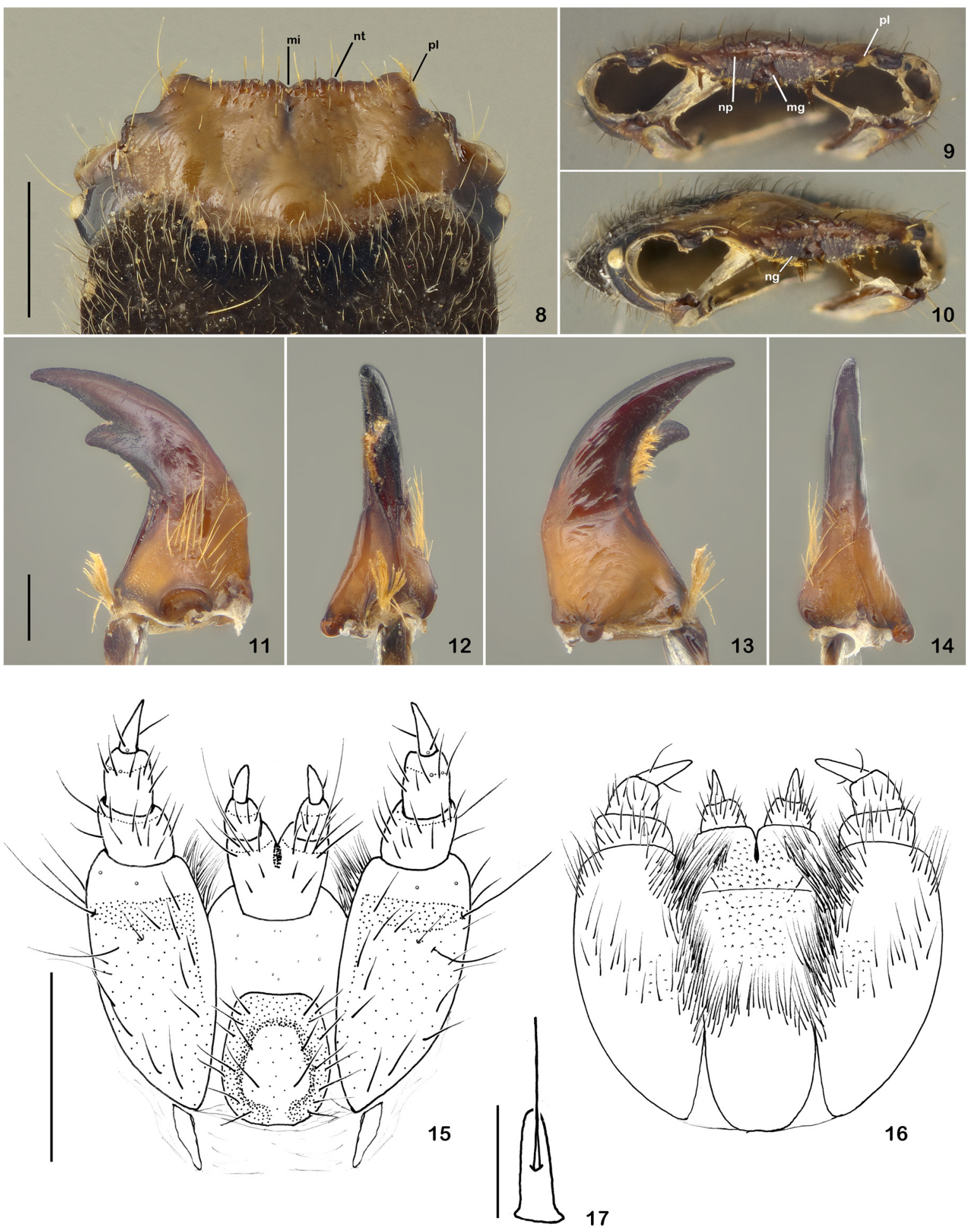

Figs 8-17. Last instar larva of Daiphron bipartitus Pic, 1934. 8-10 - head capsule, antennae and mouthparts removed (dorsal, frontal, fronto-lateral); 11-14 - right mandible (dorsal, mesal, ventral, lateral view); 15 - maxillo-labial complex; 16 - hypopharynx; 17 - galea. Scale bars: 8-10, 15, 16 - 0.5 $\mathrm{mm}$; 11-14-0.2 mm; $17-0.05 \mathrm{~mm}$. Abbrevations: mg - median groove; mi - median incision; $\mathrm{np}$ - nasal plate; nt - nasal teeth; $\mathrm{pl}$ - paranasal lobe.

15-16). Postmentum elongate, translucent with circular brownish sclerotized area at base, with numerous long setae along lateral edges, dorsal area covered with microspines distally, without ramified setae. Prementum translucent with elongate sclerite between palpigers; numerous long setae near anterior margin, and one longer seta on each side; hypopharynx (dorsal area) covered with microspines and long setae. Palpi with two palpomeres; basal palpomere longer than wide, setose; setae long, denser on ventral surface; distal palpomere elongate, tapering towards apex, with one lateral seta, one ventral seta, and one campaniform sensillum ventrally at base. Legs (Fig. 22) long, increasing in size from anterior to posterior; densely setose; setae yellow, a few longer setae on ventral margin of trochanter, femur and tibia; coxae inserted distant one from the other; femora as wide as trochanter, 


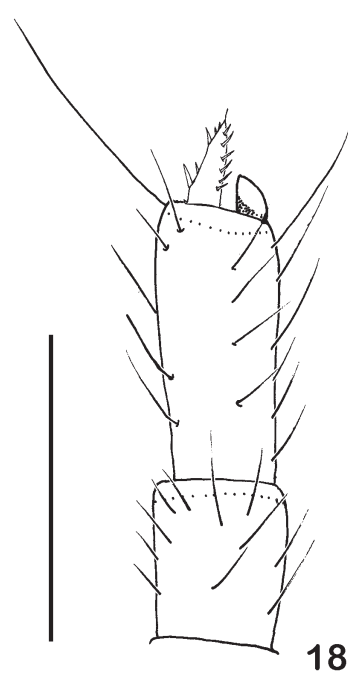

18

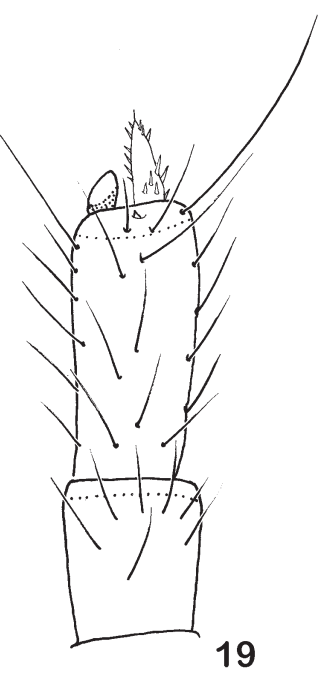

19

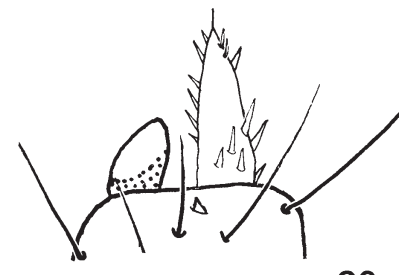

20

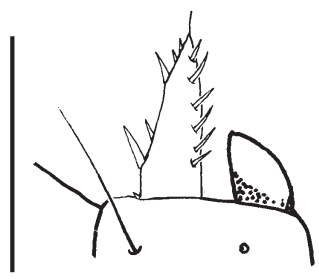

21

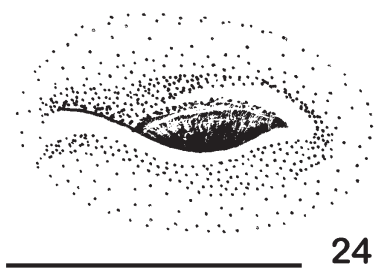

24

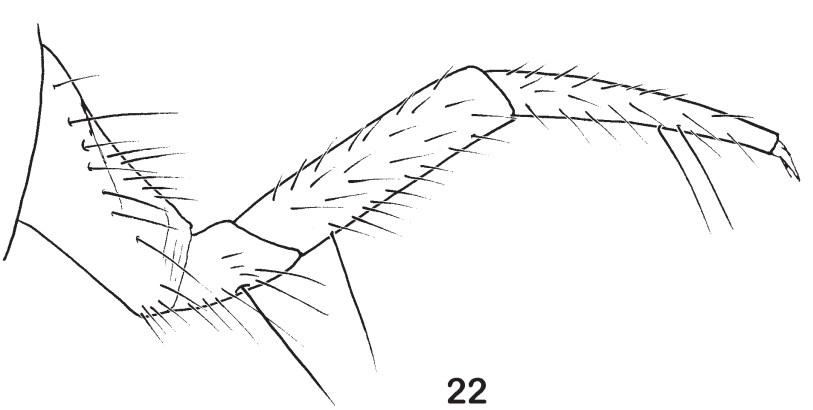

22

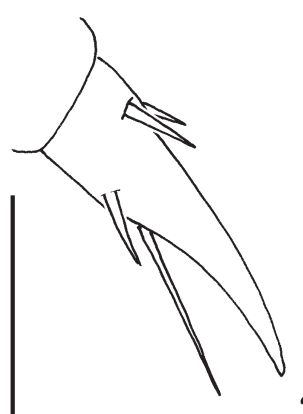

Figs 18-25. Last instar larva and pupa of Daiphron bipartitus Pic, 1934. 18-19 - right antenna (18 - dorsal view, 19 - ventral view). 20-21 - apex of right antenna (20 - ventral view, 21 - dorsal view); 22 - right prothoracic leg; 23 - pretarsus of prothoracic leg; 24 - mesothoracic spiracle; 25 - pupal abdominal tergite IX and urogomphi. Scale bars: $18-19-0.25 \mathrm{~mm} ; 20,21,23,24-0.05 \mathrm{~mm} ; 22,25-1.0 \mathrm{~mm}$.

as long as tibiae; tibiae tapering apicad; pretarsi (Fig. 23) with four stout setae; one basal seta straight, reaching or surpassing apex of pretarsus. Thorax and abdomen. Pro-, meso- and metathorax and abdominal segments I-IX with one pair of latero-dorsal glandular pores each. Meso- and metathoracic and abdominal glandular pores I-VIII on latero-dorsal ampullae (Fig. 1). Mesothorax with one pair of C-shaped spiracles located ventro-anteriorly (Fig. 24); abdominal segments I-IX with one pair of dorsolateral spiracles each, smaller than thoracic ones, located latero-anteriorly between dorsal and lateral ampullae. Abdominal segment I-V subequal in width, VI-IX gradually narrowed apicad; IX weakly widened posterad and bilobed at apex. Metathorax and abdominal segments I-VIII with median anterior transverse ampulla. Abdominal sternites I-VIII with long and thick setae arranged in one pair of tufts per segment (Fig. 7); sternite IX with long setae, denser near apex. Segment X reduced, membranous and bilobed.

Measurements of one fixed larva. Body length approx. $14 \mathrm{~mm}$; head $1.1 \times$ as long as wide, $0.8 \times$ narrower than prothorax; prothorax $1.3 \times$ longer than wide.

Pupa (Figs 25-28). Pubescence long, dense, bristly and light brown, inserted in dark punctures. Pronotum with pair of glandular pores, near fore angles, smaller than abdominal ones. Abdominal segments I-VIII with one pair of glandular pores each; each glandular pore at apex of tubular projection. One pair of lateral round spiracles on mesothorax and on abdominal segments I-VIII; last spiracle smaller. Palpi slightly sclerotized; abdominal segment IX (Fig. 25) densely setose, denser laterally at base, with pair of strongly sclerotized urogomphi; apices of urogomphi curved, with 4-5 projections with short and sharpened spines.

Measurements. Body length $12 \mathrm{~mm}$; head (up to base of mandibles) as long as wide; pronotum $1.3 \times$ wider than long, $1.4 \times$ wider than head width.

Redescription of the adult (Figs 29-45). Colouration. Head, antennae, palpi, thorax, legs and abdomen dark brown to pitch-black, sometimes clearer in front of eyes and lateral margin of clypeus; pronotum orangish yellow with broad black band extending longitudinally from anterior to posterior margin; scutellum black; elytral background orangish-yellow, black in distal two-thirds, sometimes with broad round black spot around scutellum, which may be merged with distal black marks, leaving two narrow humeral yellow bands; wings yellow on basal third and light brown in distal two thirds. Body densely covered with short pubescence and sparse longer setae, more concentrated on tibiae and tarsi.

Structure. Male (Fig. 29). Head (Figs 31-33) elongate, narrow, slightly compressed dorsoventrally; $1.7 \times$ longer than wide behind eyes; eyes large, very prominent, $1.3 \times$ 


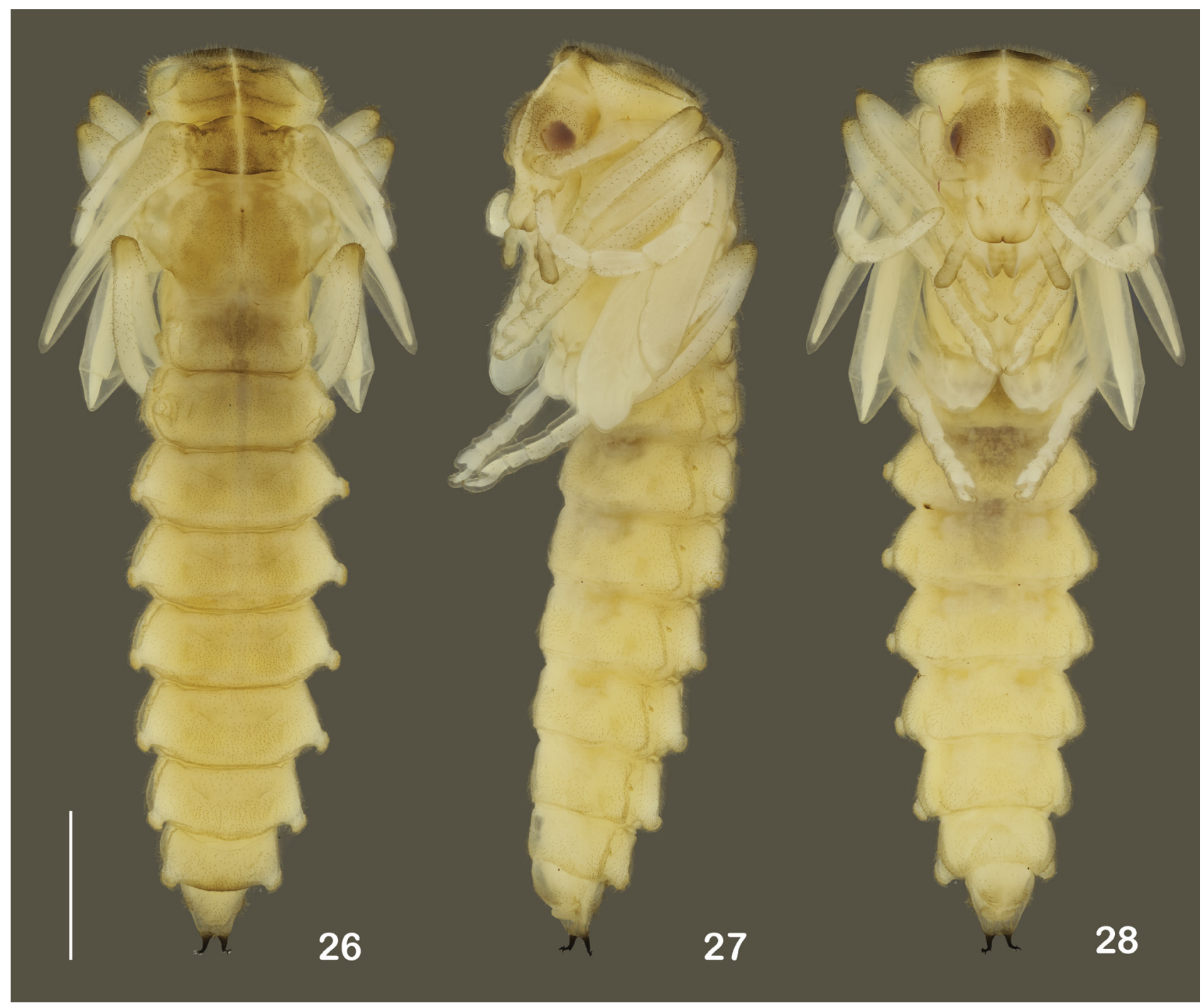

Figs 26-28. Habitus of pupa of Daiphron bipartitus Pic, 1934 (dorsal, lateral and ventral view). Scale bar: 2.0 mm.

wider than head width; head narrow and elongate in front of eyes, sides nearly parallel, slightly convergent; clypeus long and broad; fronto-clypeal suture broadly arched, distal margin slightly emarginated. Maxillae and labium long and narrow; maxillary palpi long, fourth palpomere $2.7 \times$ longer than wide. Antennae (Fig. 34) robust; antennomere I almost cylindrical, slightly swollen apically; antennomeres II and III very short, subequal in length, each $3.2 \times$ shorter than antennomere I; antennomeres IV-X subserrate, broad, slightly compressed dorsoventrally; antennomere XI narrow, cylindrical, elongate. Pronotum (Fig. 36) subtrapezoidal, 1.3× wider than long, wider posteriorly, lateral margins arched, convergent anteriorly, forming flattened flaps directed upwards; anterior margin and angles broadly arched; a rounded elevation on the disk posteriorly with a central impression. Elytra (Fig. 29) long, 3.1× longer than humeral width; sides nearly parallel, slightly wider posteriorly; apices rounded; dorsal surface rough, sometimes lustrous; each elytron with one distinct longitudinal costa fading near the apex. Wings venation (Fig. 38): radial cell 2R1 closed; Rr extending up until reaching r-m; $\mathrm{Cu}$ curved, running from anterior third of $\mathrm{M} 3+4 ; \mathrm{Mr}$ and
Ax2 sclerotized; transverse cu-a absent; margin of anal area slightly sinuous. Legs long and slender, increasing in size posteriorly; tarsal claws simple. Abdomen weakly sclerotized; ventrites I- VI wide, entire, not indented; distal margin of ventrite VII strongly notched, U-shaped; ventrite VIII oblong and strongly convex. Abdominal glandular pores broad. Aedeagus (Figs 39-42) asymmetrical. Right paramere flat, entire, bent to the right, apex rounded with a small tip directed outwards. Left paramere broad and flat, turned to the left; apex with a long projection curved to the left. Median lobe short and broad, slightly twisted in its longitudinal axis to the left; ventral face with short well-marked longitudinal keel between parameres; dorsal surface short, rough; apex broad, weakly sclerotized.

Female (Fig. 30). Usually slightly larger than males; eyes less prominent; antennae (Fig. 35) more robust, antennomeres I-III similar to males, IV-XI shorter. Pronotum (Fig. 37) less wide than in males; lateral margins broadly arched posteriorly; anterior angles less arched; posterior elevation and central impression less pronounced than in males. Seventh abdominal ventrite (Fig. 43) wider than long, distal margin broadly sinuate; two broad rounded 

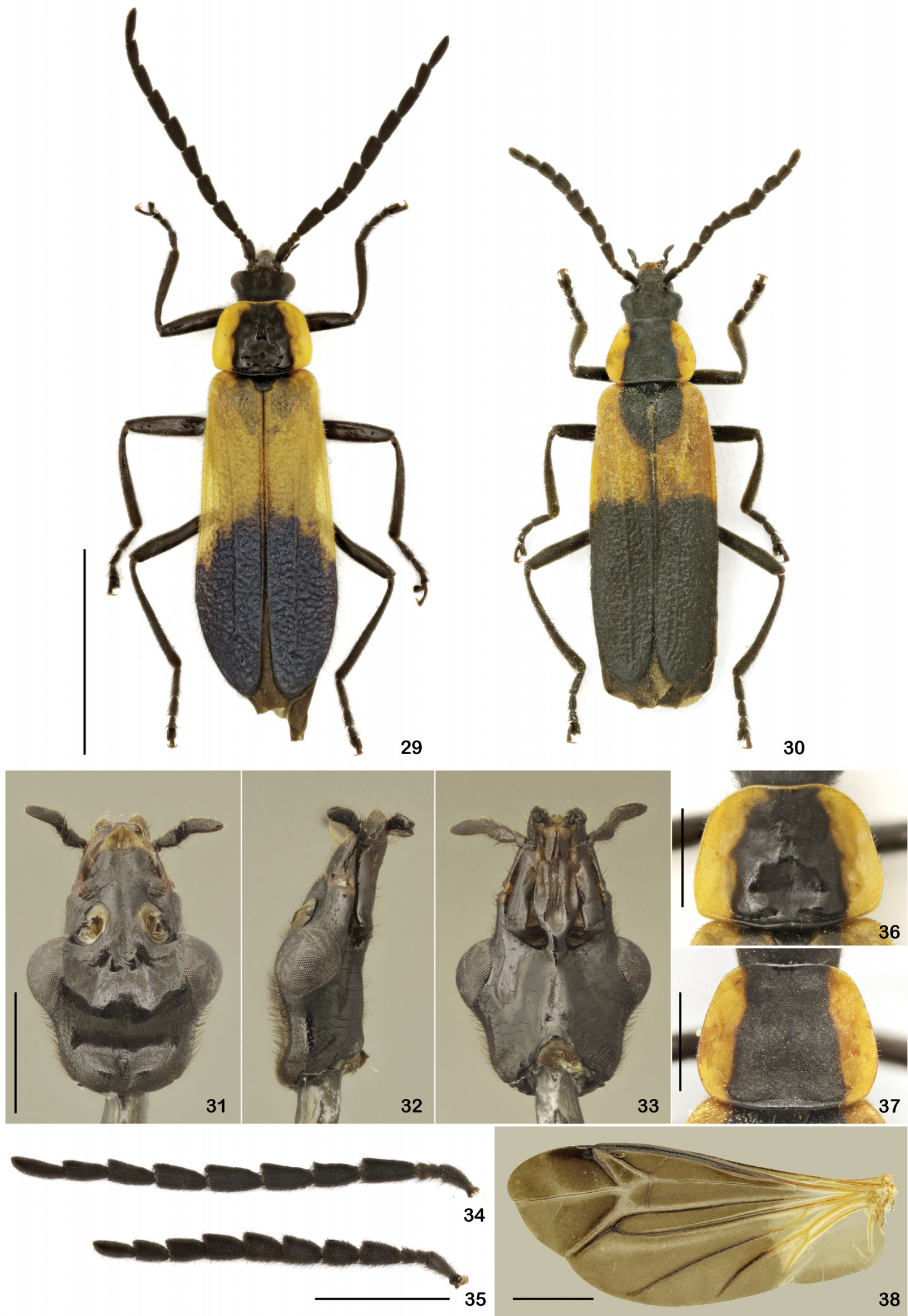

Figs 29-38. Daiphron bipartitus Pic, 1934, morphology of adults. 29-30 - dorsal habitus of adults(29-male; 30 - female). 31-33 - head of male in dorsal, lateral and ventral view (antennae removed); 34 - antenna of male; 35 - antenna of female; 36 - pronotum of male; 37 - pronotum of female; 38 - wing, dorsal view. Scale bars: $29-30-5.0 \mathrm{~mm} ; 31-33,36-37-1.0 \mathrm{~mm} ; 34-35,38-2.0 \mathrm{~mm}$. 


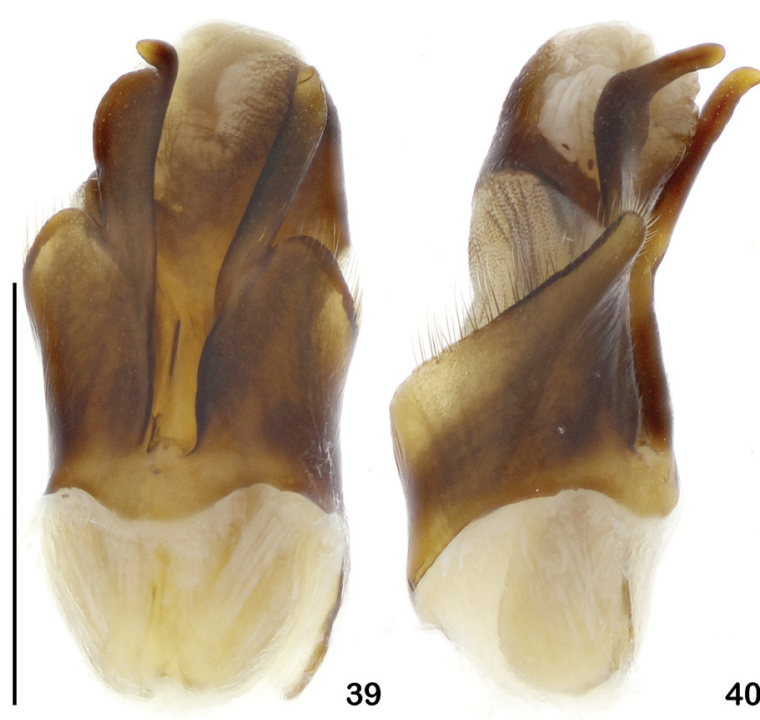

40

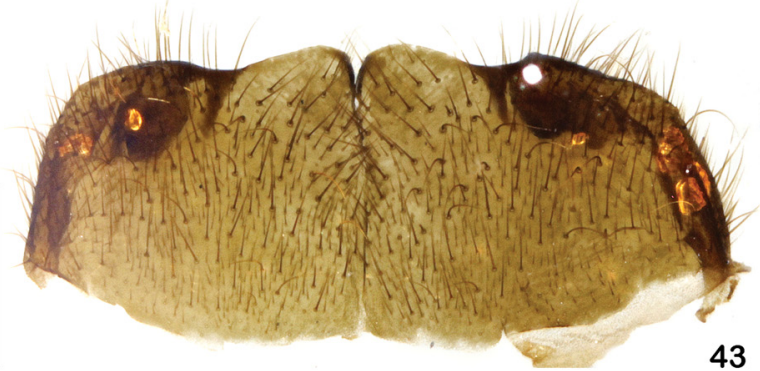

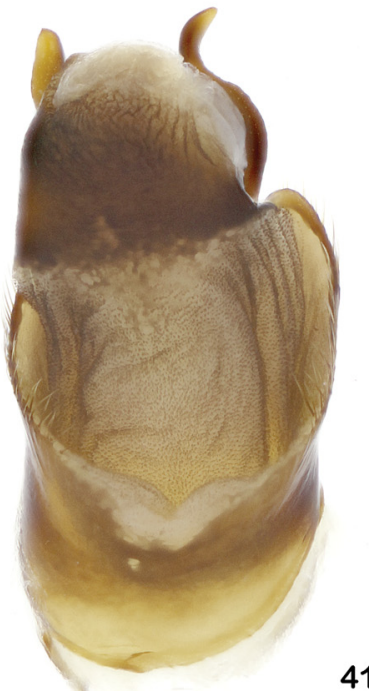
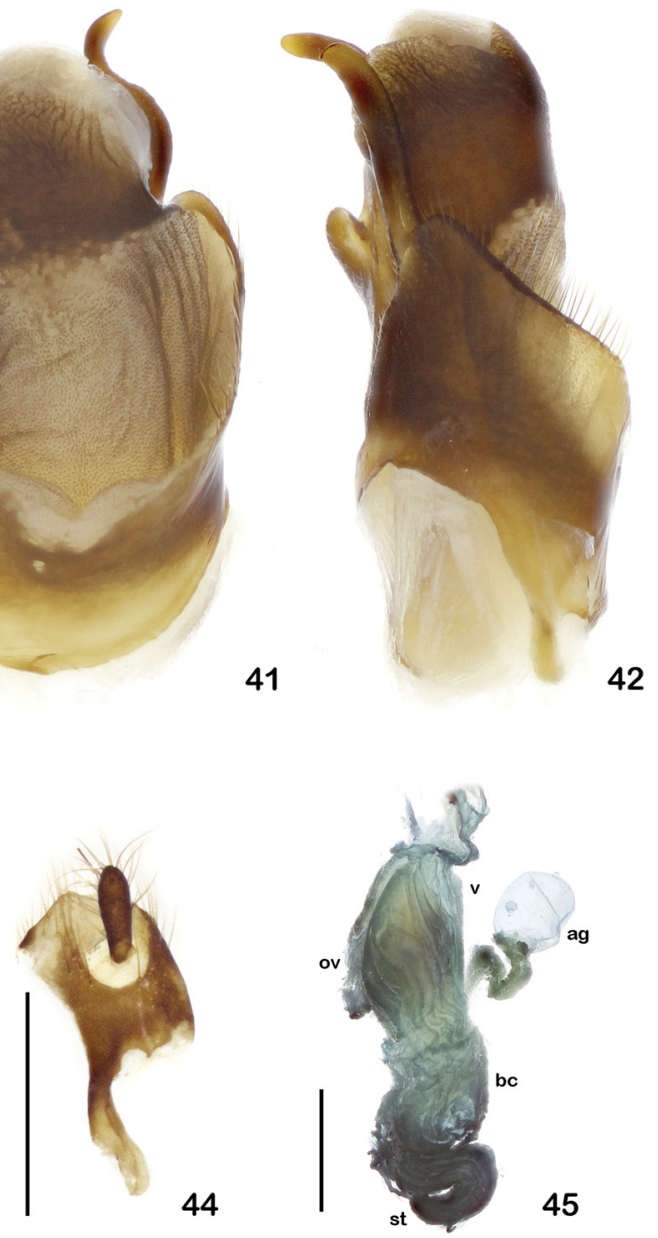

Figs 39-45. Daiphron bipartitus Pic, 1934, morphology of adults. 39-42 - aedeagus (ventral, left, dorsal, right view); 43 - sternite VII of female, ventral; 44 - right coxite of female, ventral view; 45 - female genitalia, right view. Abbreviations: ag - accessory gland; bc - bursa copulatrix; ov - oviduct; st - spermatheca, v - vagina. Scale bars: $39-42-1.0 \mathrm{~mm} ; 43-45-0.5 \mathrm{~mm}$.

lobes meeting medially, forming a weak internal longitudinal keel. Coxites (Fig. 44) elongate, slender anteriorly and short and broad posteriorly; styles very short, slightly wider apically; long setae concentrated on apex of style and on distal surface of coxite, around style. Genitalia (Fig. 45): vagina membranous, sacciform; oviduct joining posterior region of vagina; bursa copulatrix short, globose; spermatheca consisting of dense tuft of long filaments joining anterior region of bursa copulatrix; accessory gland long, sinuous, globose distally, in dorsal region of bursa copulatrix.

Measurements. Body length: 11.0-13.0 mm.

Remarks. PIC (1934) described the species as Daiphron atripenne based on a specimen with elytra nearly entirely black, and the variety $D$. atripenne var. bipartitum, with anterior half of elytra orangish yellow and posterior half black. Both phenotypes are just colour variations of the same species Daiphron bipartitus (BIFFI 2019), the latter being the most frequent amongst examined specimens.

Biological notes. One larva of Daiphron bipartitus was collected in the soil while six larvae were found amongst leaves of fallen bromeliads Vriesea bituminosa Wawra (Bromeliaceae: Tillandsioideae). Most of the larvae were found amongst the innermost, humid leaf sheaths of fallen bromeliads (Figs 46-48) during the winter, the dry season. In the laboratory, larvae were observed always inactive inside a chamber in the soil at the bottom of the container. However, they seemed to feed, since the offered termites disappeared every week. Larvae were reared for up to 36 days until they reached the pupal stage. The pupal period of three specimens lasted 6, 7, and 15 days. All the specimens of $D$. bipartitus known so far, including immatures and adults, were collected in nearby localities along Serra da Mantiqueira, at altitudes ranging from $1,400 \mathrm{~m}$ to $1,600 \mathrm{~m}$.

\section{Discussion}

The larva of Daiphron bipartitus fits the general Chauliognathinae description outlined in BIFFI \& CASARI (2017), especially into the group composed of the genera Chauliognathus and Daiphron. The main characters ascribed for this group that differ from other Chauliognathinae genera and subfamilies are: nasale with a median incision and groups of lateral teeth anteriorly (in contrast to smooth nasale in Belotus or a distinct central tooth in all other Cantharidae subfamilies); frontal plate of nasale with deep oblique grooves (in contrast to frontal plate with three 

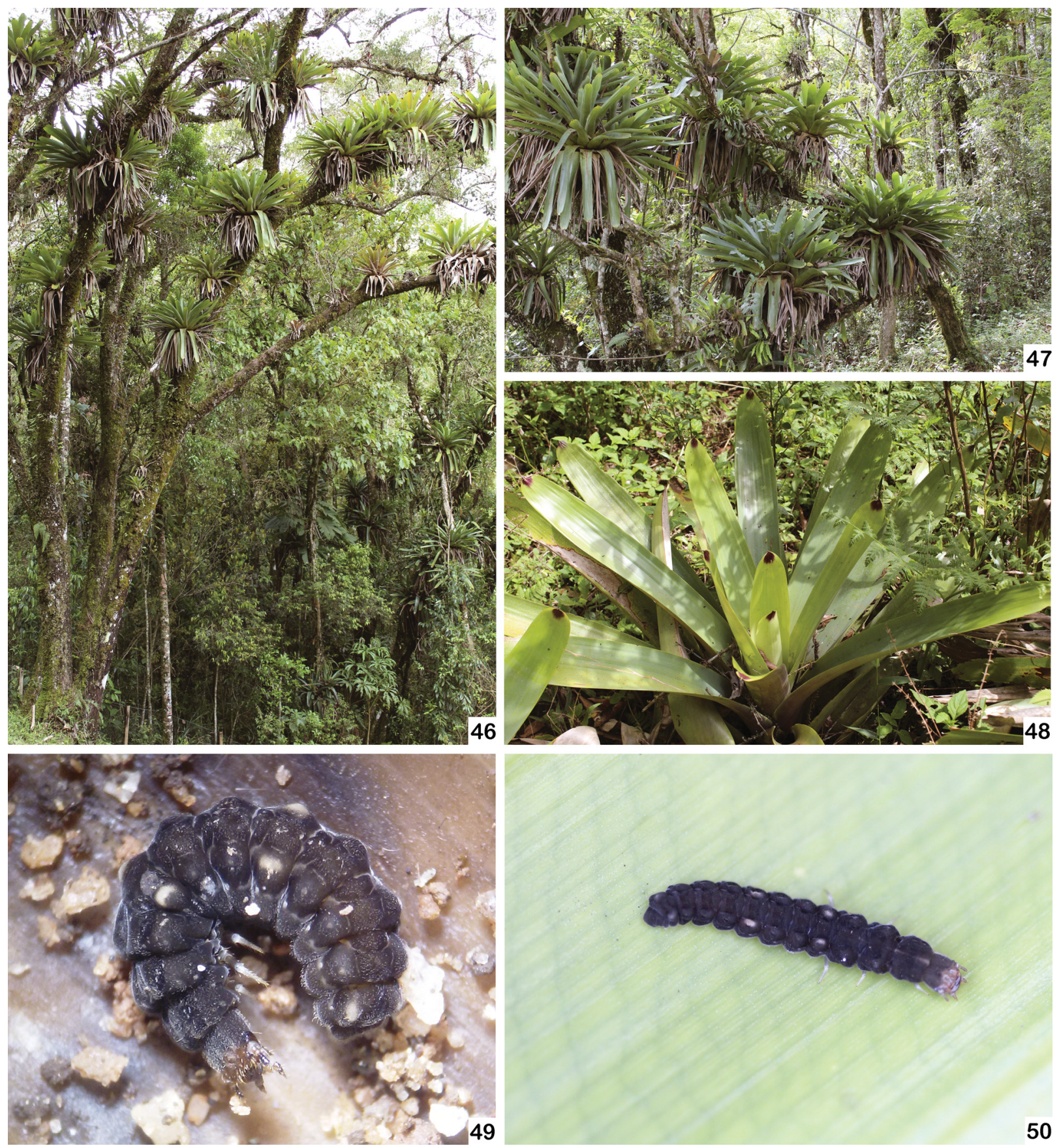

Figs 46-50. Collecting site and live Daiphron bipartitus Pic, 1934. 45-47 - Campos do Jordão (São Paulo state) with Vriesea bituminosa (Bromeliaceae); 48-49 - larva of Daiphron bipartitus.

median teeth in Macromalthinus); maxillary palpomeres 3-segmented, galea minute and penicillus of mandibles always present (in contrast to palpomeres 4-segmented, galea elongate and penicillus absent in all other Cantharidae subfamilies). Species of Chauliognathus and Daiphron can be distinguished from each other by a combination of minor features, such as the colouration and vestiture of head and body, shape and number of teeth on nasale, number and position of grooves on frontal plate of nasale, and chaetotaxy and distribution of sensilla on maxillary and labial palpomeres, antennae and pretarsi.

Daiphron mediofasciatum is the only species of the genus whose immatures have been described so far. However, despite being considered as congeneric, immature features of Daiphron bipartitus and D. mediofasciatum differ from each other, each resembling larvae of a different species of Chauliognathus (Figs 51-66). For example, Daiphron bipartitus and Chauliognathus humeralis Pic, 1915 have anterior margin of nasale toothed medially and smooth laterally (Figs 55-56), in contrast to D. mediofasciatum and C. unifasciatus Pic, 1928, with anterior margin of nasale toothed throughout (Figs 57-58); pretarsi of D. bipartitus and C. humeralis are short, bearing three short and one long seta, reaching the apex or pretarsus (59-60), whilst in D. mediofasciatum and C. unifasciatus the pretarsus is longer, more arcuate and bears four short setae (Figs 61-62); pupal urogomphi of $D$. 

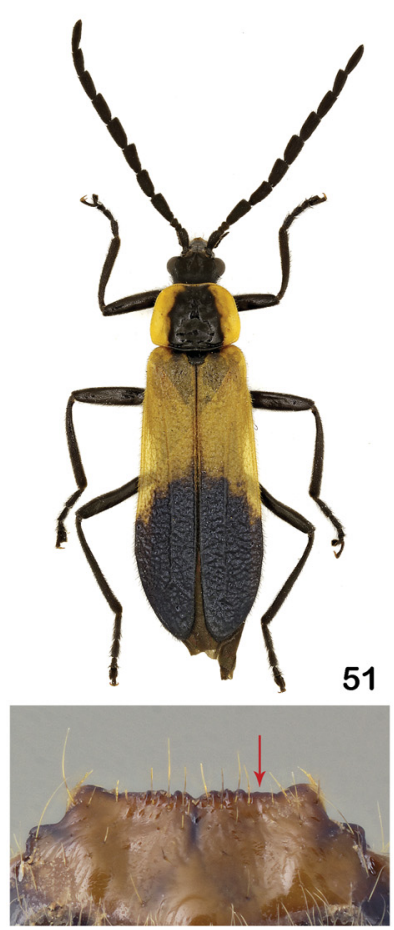

55

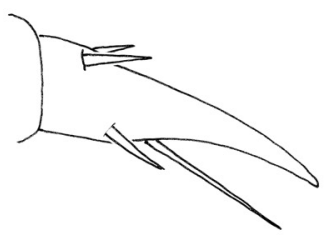

59

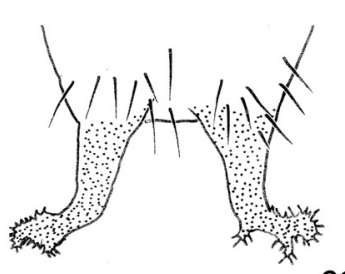

63

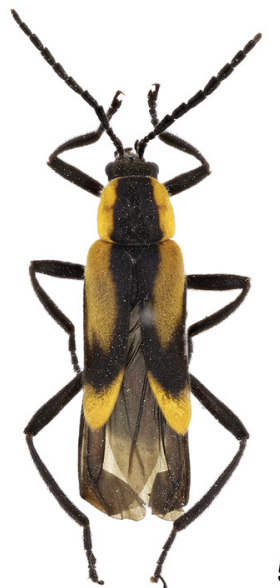

52

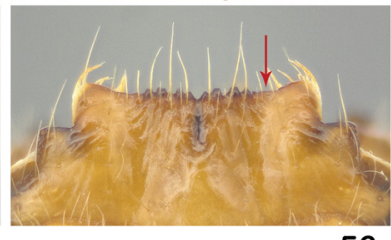

56

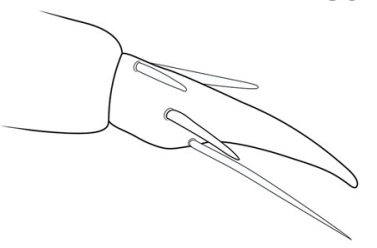

60

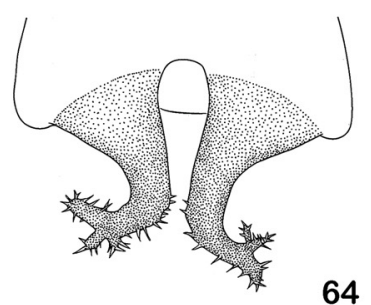

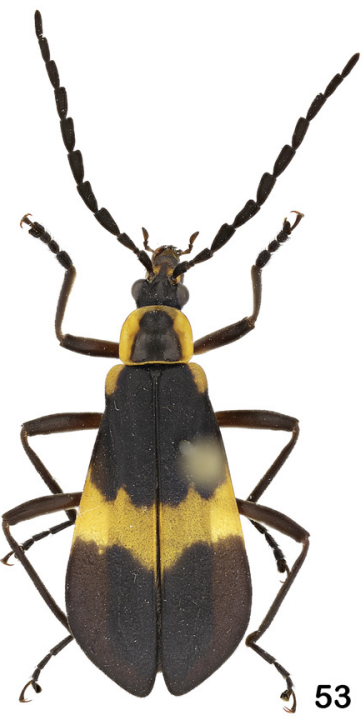
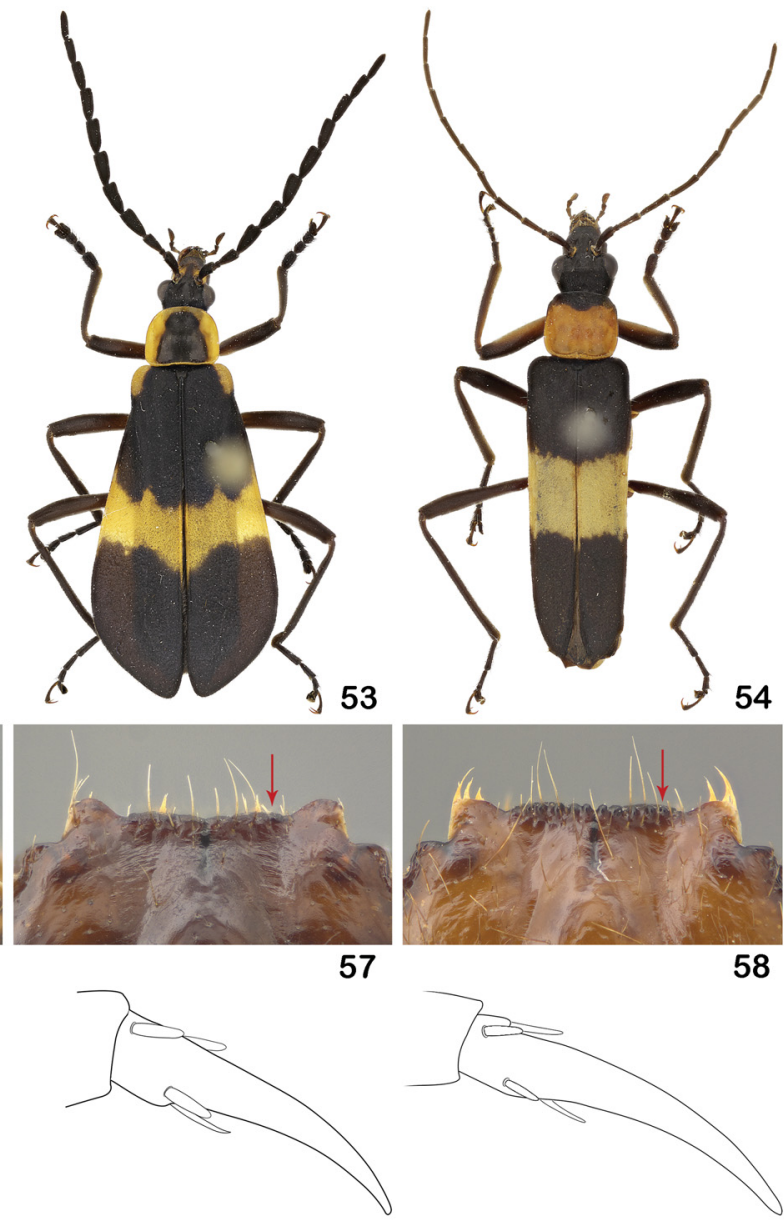

61

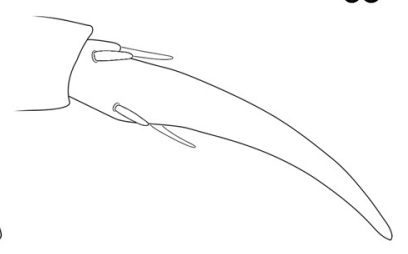

62

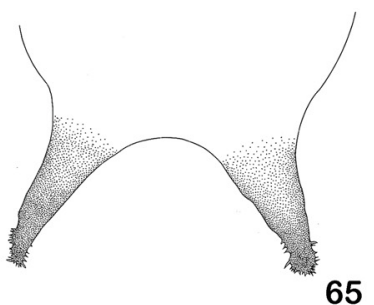

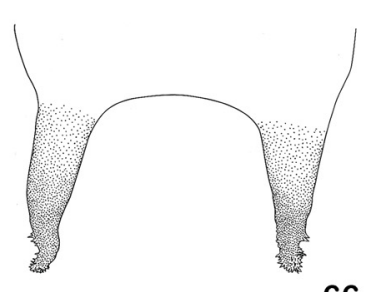

66

Figs 51-66. Comparative morphology of Chauliognathus and Daiphron species. 51, 55, 59, 63 - Daiphron bipartitus Pic, 1934; 52, 56, 60, 64 - Chauliognathus humeralis Pic, 1915; 53, 57, 61, 65 - Daiphron mediofasciatum Pic, 1949; 54, 58, 62, 66 - Chauliognathus unifasciatus Pic, 1928; 51-54 - dorsal habitus of adults; 55-58 - nasale of larva, arrow indicates anterior margin laterally smooth (55-56) or toothed (57-58); 59-62 - pretarsus of larva; 63-66 - urogomphi of pupa, dorsal view. 56-58, 60-62, 64-66 modified from BIFFI \& CASARI (2017).

bipartitus and $C$. humeralis have apices curved, ramified, bearing strong and sharpened spines (Figs 63-64), in contrast with urogomphi of $D$. mediofasciatum and $C$. unifasciatus straight, with minute apical spines (Figs 65-66).

The resemblance between $D$. mediofasciatum and $C$. unifasciatus has already been pointed out by BIFFI \& $\mathrm{CA}_{\mathrm{A}}$ SARI (2017), and the phylogeny of Chauliognathinae based on adult characters (BIFFI 2017a) confirmed their close relationships, making both genera polyphyletic within the subfamily. The morphology of immatures of Daiphron bipartitus, which is more similar to Chauliognathus humeralis than to other Daiphron, further corroborates the polyphyly of the genus.

Besides the characters listed above, Daiphron bipartitus resembles Chauliognathus humeralis also in other imma- ture and adult characters. Larvae of both species share the following set of characters: head capsule with sinuous darker markings in the middle; greyish integument, with pale-yellow spots on dorsal abdominal ampulla, thin longitudinal yellow lines along internal limits of dorsal abdominal ampulla; paranasal lobes longer than nasale, emarginate latero-internally; nasale with rounded teeth; mandibles bicolour, apex of retinaculum round; galea minute, bearing one long seta near the middle. Pupae of both species are covered with long, dense bristly pubescence; urogomphi strongly sclerotized, separated. Besides the morphology, larvae of both species present similar biology, being found amongst leaves of recently fallen bromeliads. However, the small number of larvae found in 60 investigated bromeliads indicates that these are likely not the exclusive habitat for 
larvae of Daiphron bipartitus. They benefit from the humid environment and prey, mainly numerous larvae of Scirtidae (Coleoptera) and Diptera found in almost all bromeliads.

Larvae of $D$. bipartitus differ from $C$. humeralis in the general colouration of the integument, especially in the thoracic pair of longitudinal dark spots and the pale-yellow spots on apex of dorsal ampulla of abdominal segments I, IV, and VIII. In C. humeralis the integument is lighter, with pale-yellow spots on dorsal ampulla of abdominal segments I-VIII. Nasale has five teeth on each side of median incision and nasal plate with shallow irregular grooves in D. bipartitus, whilst $C$. humeralis has four teeth on each side of nasale and nasal plate with deep grooves. Urogomphi of $D$. bipartitus are straight at base and curved at apex, with 4-5 projections with short spines; in C. humeralis they are more broadly curved from base, with three stronger projections with longer spines.

Adults of Daiphron bipartitus and Chauliognathus humeralis have in common an elongate head; antennae robust, antennomeres wide, subserrate, densely setose, antennomere III very short; pronotum subtrapezoidal, sides arched; legs densely covered with thick long setae; seventh abdominal ventrite of females with distal margin distinctly notched, slightly folded inside medially; aedeagus slightly flattened dorsoventrally, median lobe robust with apex broadly membranous, parameres flat, slightly twisted laterally, tips curved and directed outwards.

In some aspects adults of Daiphron bipartitus and Chauliognathus humeralis resemble the species of Psilorrhynchus Gemminger \& Harold, 1869, which also have elongate heads with prominent eyes, broad trapezoidal pronotum and robust aedeagus, with median lobe short and stout, and parameres flat with rounded tips (BIFFI 2017b). The affinity between $D$. bipartitus and $C$. humeralis indicated from the immature characters is also corroborated by adult morphology. The immature forms of Psilorrhynchus, still unknown, may as well provide further information to accurately infer their relationships.

\section{Acknowledgements}

We are grateful to the museum curators Thierry Deuve, Azadeh Taghavian (MNHN), Matthias Borer, Isabelle Zürcher (NHMB), and Lúcia M. Almeida (DZUP) for providing access to specimens under their care. Thanks to Fabiano F. Albertoni for help in identifying the bromeliads, to Tânia A. Barbosa (UNIFEI) for collecting termites and helping feed the larvae, and to Michael Geiser, Fabiano Albertoni, Martin Fikáček, and one anonymous reviewer for corrections and suggestions on the manuscript. Part of this work was supported by grants to GB from São Paulo Research Foundation (FAPESP-2013/08966-1; FAPESP-2015/21273-0).

\section{References}

BLACKWELDER R. E. 1945: Checklist of the coleopterous insects of Mexico, Central America, the West Indies and South America. Bulletin of the United States National Museum 185: 345-550.

BIFFI G. 2016: On the identity of Chauliognathus flavipes (Coleoptera: Cantharidae): revision of type specimens, new synonyms and new status. Zoologia 33(e20160088): 1-20. DOI: 10.1590/S19844689zool-20160088

BIFFI G. 2017a: Análise cladística de Chauliognathini sensu Miskimen, 1961 e revisão de Microdaiphron Pic, 1926 (Coleoptera, Cantharidae, Chauliognathinae). Doctoral Thesis, Instituto de Biociências, Universidade de São Paulo, São Paulo, VIII + 232 pp.

BIFFI G. 2017b: Taxonomic revision of Psilorrhynchus Gemminger \& Harold, 1869, the neglected replacement name for Psilorhynchus Blanchard, 1844 (Coleoptera: Cantharidae). Annales de la Société Entomologique de France (Nouvelle Série) 53: 131-142, DOI: 10.1080/00379271.2017.1318302

BIFFI G. 2019: Taxonomic revision of Microdaiphron Pic, 1926 (Coleoptera: Cantharidae: Chauliognathinae). Insect Systematics and Evolution [1-36]. DOI: 10.1163/1876312X-00002208

BIFFI G. \& CASARI S.A. 2017: Comparative morphology of immatures of neotropical Chauliognathinae (Coleoptera, Cantharidae). Zoologischer Anzeiger 267: 111-138. DOI: doi.org/10.1016/j.jcz.2017.02.003

BRANCUCCI M. 1980: Morphologie comparée, évolution et systématique des Cantharidae (Insecta: Coleoptera). Entomologica Basiliensia 5: 215-388.

COSTA C., VANIN S. A. \& CASARI-CHEN S. A. 1988: Larvas de Coleoptera do Brasil. Museu de Zoologia, Universidade de São Paulo, São Paulo, 165 plates, 282 pp. DOI: doi.org/10.5962/bhl.title. 100233

DELKESKAMP K. 1939: Col. Cantharidae. In: SCHENKLING S. (ed.): Coleopterorum Catalogus. Pars 165. Dr. W. Junk, s'Gravenhage, $357 \mathrm{pp}$.

DELKESKAMP K. 1977: Col. Cantharidae. In: WILCOX J.A. (ed.): Coleopterorum Catalogus Supplementa. Pars 165, fasc 1. Dr. W. Junk, The Hague, 485 pp.

DELKESKAMP K. 1978: Col. Cantharidae, Corrigenda et Addenda. In: WILCOX J. A. (ed.): Coleopterorum Catalogus Supplementa, Pars 165, fasc. 2. Dr. W. Junk, The Hague, 486-556 pp.

KÖPPEN W. \& GEIGER R. 1928: Klimate der Erde. Verlag Justus Perthes, Gotha, Wall-Map $150 \mathrm{~cm} \times 200 \mathrm{~cm}$.

KOTTEK M., GRIESER J., BECK C., RUDOLF B. \& RUBEL F. 2006: World map of Köppen-Geiger climate classification updated. Meterologische Zeitschrift 15: 259-263.

LAWRENCE J. F., BEUTEL R. G., LESCHEN R. A. B. \& ŚLIPIŃSKI A. 2010: Glossary of morphological terms. Pp. 9-20. In: LESCHEN R. A. B., BEUTEL R. G. \& LAWRENCE J. F. (eds.): Handbook of Zoology, Volume 2. Coleoptera: Morphology and Systematics (Elateroidea, Bostrichformia, Cucujiformia Partim). Walter de Gruyter $\mathrm{GmbH} \& \mathrm{Co}$, Berlin/New York, xiii + 786 pp.

PIC M. 1934: Malacodermes exotiques. L'Échange, Revue Linnéenne 50(456, hors-texte): 129-132.

RAMSDALE A. S. 2010: 4.17. Cantharidae Imhoff, 1856. Pp. 153-162. In: LESCHEN R. A. B., BEUTEL R. G. \& LAWRENCE J. F. (eds.): Handbook of Zoology, Volume 2 Coleoptera: Morphology and Systematics (Elateroidea, Bostrichformia, Cucujiformia Partim). Walter de Gruyter GmbH \& Co., Berlin/New York, xiii + 786 pp.

ROBIM M. J. \& PFEIFER R. M. 1989: Correlações de características do meio biofísico do Parque Estadual de Campos do Jordão, SP. Anais do XXXIX Congresso Nacional de Botânica. Acta Botanica Brasilica 2: 175-181. 